DOI: https://doi.org/10.24127/ajpm.v9i4.3199

\title{
BAGAIMANA KONSEPSI GURU SEKOLAH MENENGAH PERTAMA TENTANG REPRESENTASI DALAM PEMBELAJARAN MATEMATIKA?
}

\author{
Sadrack Luden Pagiling ${ }^{1 *}$, Anis Munfarikhatin ${ }^{2}$ \\ ${ }^{1 *, 2}$ Universitas Musamus, Merauke, Indonesia \\ *Corresponding author. Jl Kamizaun Mopah Lama, 99611, Merauke, Indonesia. \\ E-mail: $\quad$ pagiling_fkip@unmus.ac.id ${ }^{1)}$ \\ munfarikhatin_fkip@unmus.ac.id ${ }^{2)}$
}

Received 02 November 2020; Received in revised form 09 December 2020; Accepted 20 December 2020

\begin{abstract}
Abstrak
Representasi sangat penting dalam pengajaran dan pembelajaran matematika di kelas. Namun, guru belum menjadikan representasi sebagai aktivitas otentik dalam berpikir dan menjelaskan ide-ide matematis. Karena itu, penelitian bertujuan untuk mengeksplorasi konsepsi guru SMP tentang representasi dalam pembelajaran matematika ditinjau dari pengalaman mengajar. Tiga guru matematika dengan pengalaman mengajar berbeda dari tiga sekolah berbeda di Kabupaten Merauke menjadi subjek pada penelitian ini. Tes dan wawancara diberikan kepada ketiga guru untuk mengungkap konsepsi guru tentang representasi matematis. Hasil penelitian menunjukkan bahwa guru dengan lama mengajar 3 tahun memiliki konsepsi tentang representasi sebagai alat untuk memecahkan masalah dan belum menggunakan representasi sebagai pusat pembelajaran matematika, guru dengan lama mengajar 6 tahun memiliki konsepsi tentang representasi sebagai alat untuk memecahkan masalah dan untuk mengilustasikan ide-ide matematis, dan guru dengan lama mengajar 8 tahun meyakini bahwa representasi penting untuk memahami konsep matematika, menjelaskan ide-ide matematis, dan memecahkan masalah. Implikasi penelitian ini menyarankan guru matematika untuk memulai pembelajaran dengan representasi dengan menggunakan benda-benda di sekitar agar siswa bisa bereksplorasi dalam mengonstruksi pemahaman dan pengetahuan matematika secara mandiri.
\end{abstract}

Kata kunci: Guru SMP; pembelajaran matematika; representasi.

\begin{abstract}
Representation is very significant in mathematics teaching and learning in the classroom. However, the teacher has not created and build representations as an authentic activity in thinking and explaining mathematical ideas. Therefore, this study seeks to explore the middle school teacher's conception of representations in mathematics teaching and learning viewed from teaching experience. Three mathematics teachers with different teaching experiences came from three distinct schools in Merauke regency became participants of this study. Test and interview were assigned to the three teachers to reveal their mathematical representations conception. This work's results indicate that teacher with 3year teaching experience had a conception of representations as a tool to solve problems, the teacher with 6-year teaching experience had a conception of representations as a tool to solve problems and to illustrate mathematical ideas, and teacher with 8-year teaching experience believes that representations are important for understanding mathematical concepts, explaining mathematical ideas, and solving problems. The implication of this study advocates that mathematics teachers to initiate learning with representations by using objects around them so that students can explore in constructing mathematical understanding and knowledge autonomously.
\end{abstract}

Keywords: mathematics learning; middle school teacher; representation.

This is an open access article under the Creative Commons Attribution 4.0 International License 
DOI: https://doi.org/10.24127/ajpm.v9i4.3199

\section{PENDAHULUAN}

Representasi didefinisikan sebagai entitas atau konfigurasi karakter, gambar, benda konkret yang dapat melambangkan atau yang mewakili sesuatu yang lain (Goldin \& Shteingold, 2001; Mitchell et al., 2014; Stylianou, 2010). Representasi bisa merujuk ke proses dan produk, yaitu tindakan atau proses untuk memahami konsep matematika atau hubungan di antara konsep tersebut (NCTM, 2000; Pagiling, 2019).

Pada pembelajaran matematika, representasi bisa dijumpai dalam berbagai bentuk seperti gambar, grafik, tabel, diagram, notasi matematika, situasi kontekstual, dan kata-kata atau frase yang digunakan untuk memahami dan mengomunikasikan ide-ide matematis (Anantharajan, 2020; Selling, 2016; Yee \& Bostic, 2014). Guru dapat menggunakan representasi sebagai bagian integral dalam pembelajaran matematika. Representasi bisa menjadi suatu proses yang kompleks dan sederhana. Hal ini bergantung pada guru dalam menjelaskan konsep baru, memberikan ilustrasi dalam proses pemecahan masalah, dan melakukan koneksi di antara beberapa konsep matematika.

Lebih jauh lagi, guru dapat menggunakan representasi tertentu dalam menjelaskan suatu materi atau konsep matematika bergantung pada tujuan pembelajaran. Pada kasus seperti ini representasi berfungsi alat untuk menjelaskan konsep matematika (Goldin, 2000; Hoogland et al., 2018). Selain itu, representasi yang dikonstruksi baik oleh guru maupun siswa dapat menjadi bahan diskusi di kelas dan membantu guru dalam memantau perhatian siswa ketika memahami suatu konsep tertentu. Pada kasus ini representasi sebagai alat untuk memfasilitasi berlangsungnya diskusi di kelas (Stylianou, 2010). Terakhir, representasi yang dibangun dan digunakan oleh siswa ketika menyelesaikan soal dapat dijadikan oleh guru sebagai alat penilaian untuk memeroleh cakrawala (insight) terhadap penalaran siswa (Santia et al., 2019).

Representasi sangat signifikan dalam pembelajaran matematika khususnya dalam pemahaman konsep, koneksi di antara konsep matematika, dan pemecahan masalah (Lee \& Lee, 2019; NCTM, 2000; Rau \& Matthews, 2017). Namun, kebanyakan penelitian lebih banyak mengkaji penggunaan representasi oleh siswa dalam menyelesaikan soal matematika (Boonen et al., 2014; Selling, 2016; Yee \& Bostic, 2014) yang menekankan bahwa kesuksesan siswa dalam menyelesaikan masalah ditentukan oleh kemampuan representasi siswa yang mumpuni. Selain itu, siswa yang membangun representasi dari suatu konsep atau menggunakan representasi ketika memecahkan masalah, mereka secara alamiah cenderung mengurangi tingkat keabstrakan dari masalah yang diberikan dan menyesuaikan dengan struktur kognitif yang telah dimiliki (Panasuk \& Beyranevand, 2010).

Penelitian masih relatif jarang mendokumentasikan konsepsi guru tentang representasi khususnya dalam konteks pembelajaran matematika di kelas. Beberapa penelitian yang telah mengeksplorasi representasi dalam pembelajaran matematika menunjukkan bahwa guru dan calon guru memiliki pengetahuan baik pedagogis maupun konten yang rendah dalam mengajarkan matematika yang menuntut penggunaan representasi (Dreher \& Kuntze, 2015; Huang \& Cai, 2011; Kang \& Liu, 2018; Mitchell et al., 2014; Stylianou, 2010). Hasil penelitian (Dreher \& Kuntze, 
2015) menunjukkan bahwa calon guru dan guru dalam masa jabatan tidak sepenuhnya memahami peran kunci berbagai representasi untuk belajar matematika. Penelitian (Huang \& Cai, 2011) membuktikan bahwa penggunaan beberapa representasi secara bersamaan tampaknya menjadi tujuan instruksional untuk guru Amerika Serikat sebagai sarana untuk pemahaman siswa, sedangkan guru China memilih representasi tertentu saja secara hierarki yang digunakan sebagai sarana untuk membantu siswa memahami persamaan linier. Penggunaan berbagai bentuk representasi pada konsep atau tugas matematika yang sama dapat memperkaya guru dalam pembelajaran matematika di kelas (Kang \& Liu, 2018). Representasi menjadi hambatan bagi siswa dan menguatkan miskonsepsi siswa ketika guru menggunakan representasi tanpa disertai konstruksi pemaknaan yang benar terhadap ide-ide matematis. Hal ini terjadi ketika siswa dipaksa untuk meniru prosedur guru tanpa melakukan refleksi terhadap aktivitas atau tanpa bimbingan guru untuk mengkaitkan representasi yang dikonstruksi siswa dengan pengetahuan awal yang sudah dimiliki dalam belajar matematika (Mitchell et al., 2014). Stylianou menekankan bahwa penggunaan multi representasi secara fleksibel memiliki potensi untuk menciptakan pembelajaran yang lebih kaya, bermakna, dan efisien (Stylianou, 2010). Oleh karena itu, sebuah penelitian dibutuhkan untuk mengungkap konsepsi guru tentang representasi matematika.

Berdasarkan observasi yang dilakukan di salah satu SMP di Kabupaten Merauke ditemukan masalah bahwa guru menggunakan representasi semata-mata sebagai alat bantu dalam menyelesaikan soal. Guru belum mampu memahami secara utuh tentang representasi dalam pembelajaran matematika. Hal ini terbukti dari guru belum mengonstruksi dan menggunakan representasi sebagai komponen penting dalam pembelajaran matematika di kelas. Hal ini bertentangan dengan aktivitas matematika yang otentik di mana representasi-representasi yang terkonstruksi, berguna sebagai alat untuk berpikir dan berkomunikasi tentang matematika (Goldin \& Shteingold, 2001; Stylianou, 2011).

Penelitian tentang konsepsi guru tentang representasi matematis ini sangat penting dilakukan untuk mempromosikan representasi sebagai bagian sentral dalam pembelajaran. Konsepsi atau pemahaman guru tentang representasi akan memengaruhi pandangan guru tentang peran representasi dalam pembelajaran matematika. Guru matematika harus memiliki kemampuan representasi matematis yang baik untuk memfasilitasi siswa dalam memahami ide-ide matematis. Untuk dapat melakukan itu, guru harus memperlengkapi dirinya dengan kemampuan representasi yang memadai dalam mengajarkan matematika, seperti pembiasaan guru menyajikan masalah dalam bentuk cerita, gambar, benda nyata, dan situasi yang kontekstual untuk mengilustrasikan ide-ide matematis dan membantu siswa dalam memahami suatu konsep. Seorang guru juga harus mumpuni dalam memecahkan masalah dengan menggunakan multipel representasi yang berasosiasi dengan kesuksesan siswa dalam memecahkan masalah.

Pengalaman mengajar guru ikut berasosiasi dengan konstruksi dan penggunaan representasi matematis guru pada pembelajaran di kelas. Guru yang sudah lama mengajar diyakini 
telah sering menggunakan representasi pada pembelajaran di kelas. Berdasarkan masalah yang telah dipaparkan, penelitian ini bertujuan untuk mengeksplorasi konsepsi guru SMP tentang representasi pada pembelajaran matematika ditinjau dari pengalaman mengajar guru.

\section{METODE PENELITIAN}

Penelitian ini berfokus pada skala kecil yaitu tiga guru matematika maka pendekatan kualitatif diterapkan. Instrumen pendukung pada penelitian ini adalah tes representasi matematis (TRM) dan pedoman wawancara yang telah divalidasi. Validator menyatakan bahwa instrumen tes dan pedoman wawancara layak digunakan tanpa revisi.

Pemilihan subjek penelitian didasarkan pada pengalaman mengajar guru. Tiga guru matematika SMP di kabupaten Merauke yaitu seorang guru dengan pengalaman mengajar 3 tahun, seorang guru dengan pengalaman mengajar 6 tahun, dan seorang guru dengan pengalaman mengajar 8 tahun menjadi subjek penelitian ini. Data dikumpulkan melalui pemberian tes representasi matematis dan wawancara mendalam. Tes representasi matematis bertujuan untuk mendapatkan data tentang representasi matematis guru matematika SMP dalam menyelesaikan soal matematika. Setelah mengerjakan TRM, ketiga guru diwawancarai untuk mendapatkan data representasi matematis yang rinci. Wawancara yang digunakan adalah wawancara semi terstruktur yang bertujuan untuk mengetahui konsepsi guru tentang representasi matematis yang dikonstruksi dan digunakan pada penyelesaian masalah dan pembelajaran di kelas. Agar tidak ada informasi yang terlewatkan dan data yang diperoleh dijamin keabsahannya, wawancara direkam menggunakan smartphone. Hasil rekaman wawancara ditranskrip secara detail yang selanjutnya dipadukan dengan catatan lapangan serta hasil pengamatan peneliti selama melaksanakan wawancara.

Selanjutnya dilakukan triangulasi data untuk menguji kredibilitas data. Jenis triangulasi data yang digunakan dalam penelitian ini adalah triangulasi teknik yaitu teknik tes dan wawancara. Keabsahan data diperiksa kepada subjek yang sama dengan teknik yang berbeda yaitu memeriksa kekonsistenan data tes representasi matematis dengan wawancara. Analisis data dilakukan dengan reduksi data yaitu memfokuskan pada data representasi matematis guru, penyajian data representasi dalam bentuk gambar dan narasi kata-kata, dan penarikan kesimpulan.

\section{HASIL DAN PEMBAHASAN}

Penelitian ini diawali dengan memilih subjek yang didasarkan pada pengalaman guru mengajar matematika. Selanjutnya dilakukan studi pendahuluan untuk mengidentifikasi kondisi pembelajaran matematika di SMP selama pandemi Covid-19. Pembelajaran dilakukan secara daring dan luring yang bersifat terbatas. Berdasarkan hasil komunikasi dengan guru matematika pada 4 (empat) sekolah, satu sekolah tidak bersedia untuk jadi objek penelitian karena pandemi Covid-19. Subjek yang terpilih adalah 3 (tiga) guru perempuan matematika SMP dari 3 sekolah berbeda yaitu guru pertama dengan lama mengajar 8 tahun, guru ke-2 dengan lama mengajar 6 tahun, dan guru ke-3 dengan lama mengajar 3 tahun. Tiga guru dengan gender yang sama dipilih agar data konsepsi guru tentang representasi benar-benar disebabkan 
DOI: https://doi.org/10.24127/ajpm.v9i4.3199

oleh lamanya guru mengajar. Ketiga guru matematika SMP memiliki kemampuan komunikasi lisan dan tulisan yang baik dan bersedia untuk berpartisipasi dalam penelitian ini.

Untuk mengungkap representasi guru SMP pada pembelajaran matematika, subjek diminta untuk mengerjakan tes representasi matematis. Tes ini merupakan soal cerita yang terdiri atas 3 nomor yang memuat masalah sistem persamaan linear dua variabel, geometri, dan pola bilangan. Soal cerita dipilih karena informasi pada soal cerita tidak dituliskan secara eksplisit sehingga representasi diperlukan oleh guru untuk mengilustrasikan informasi tersebut. Wawancara mendalam dilaksanakan dengan menerapkan protokol kesehatan kepada 3 (tiga) guru SMP untuk mengungkap konsepsi guru tentang representasi matematis. Artikel ini hanya membahas hasil pekerjaan guru dalam memecahkan masalah pola bilangan dan konsepsi guru tentang representasi. Hasil pekerjaan ketiga guru SMP yaitu Ms Tata, Ms Tere, dan Ms Tasya (nama samaran) dalam mengerjakan tes representasi matematis (TRM) dapat dipaparkan berikut ini.

1. Data Representasi Matematis Guru SMP dengan Pengalaman Mengajar 8 tahun

Hasil pekerjaan guru dengan lama mengajar 8 tahun $\left(\mathrm{T}_{1}\right)$ dalam menyelesaikan TRM disajikan pada Gambar 1.

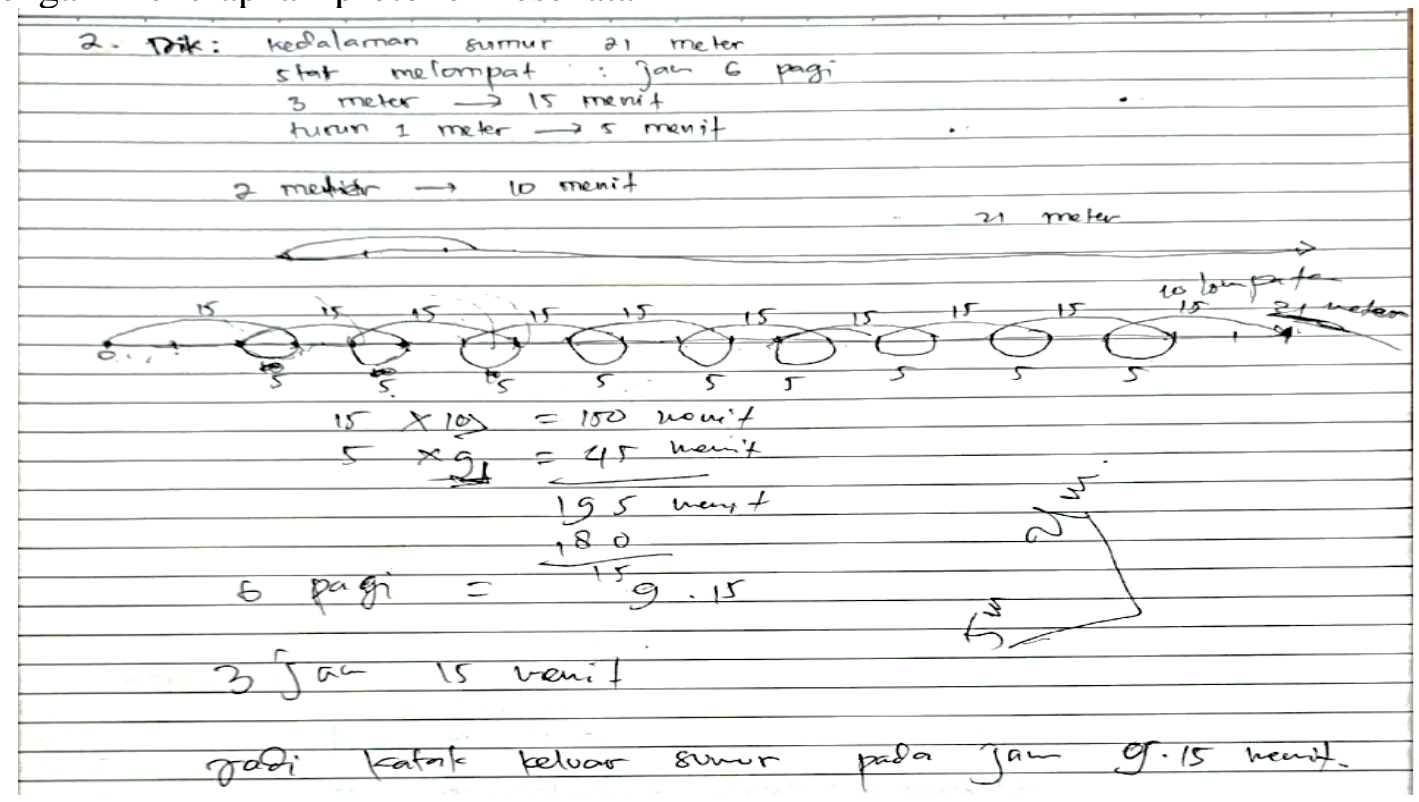

Gambar 1 Pekerjaan Ms Tata $\left(\mathrm{T}_{1}\right)$

Hasil pekerjaan Ms. Tata dalam menyelesaikan pola bilangan pada gambar 1 dan dikonfirmasi dengan hasil wawancara menunjukkan subjek 1 $\left(\mathrm{T}_{1}\right)$ menggunakan representasi verbal dan visual dalam melukiskan informasi yang diketahui di soal. $\mathrm{T}_{1}$ menuliskan informasi yang diketahui di soal dengan bahasa sendiri dalam bentuk frase atau kata-kata. Hal ini mengindikasikan bahwa $T_{1}$ menggunakan representasi verbal sebagai alat untuk memahami masalah dengan mengorganisasikan semua informasi yang tersedia pada soal. Ia mengorganisasikan semua informasi dan mengidentifikasi kecukupan informasi untuk menyelesaikan masalah. 
$\mathrm{T}_{1}$ mengungkapkan rencana atau strategi penyelesaian bahwa ia perlu menyatakan informasi yang tersedia di soal dalam bentuk gambar sehingga memudahkan dalam penyelesaian soal. Ia mengonstruksi dan menggunakan garis lurus yang menyimbolkan lintasan katak dan garis melengkung yang mengilustrasikan lompatan dan istirahat katak. Ia mengonstruksi garis lurus sepanjang 21 meter yang menyatakan kedalaman sumur.

$\mathrm{T}_{1}$ melaksanakan rencana dengan membuat sketsa lintasan yang dilalui katak yang menggambarkan lompatan dan istirahat katak sampai katak keluar sumur. Ia mengilustrasikan lompat dengan frase "maju" dan istirahat dengan frase "mundur" dan menggambarkan seperti bukit dan lembah pada sketsa lintasan katak. Hal ini mengindikasikan ia memilih representasi verbal dan visual dalam melaksanakan rencana atau strategi penyelesaian masalah.

$\mathrm{T}_{1}$ juga melaksanakan rencana penyelesaian dengan menggunakan representasi visual. Ia menuliskan waktu yang dibutuhkan katak dalam melompat yaitu 15 menit dan waktu istirahat 5 menit pada sketsa. Dia mengilustrasikan solusi secara visual sehingga ia mampu menghitung banyak lompatan dan banyak istirahat katak sampai berhasil keluar dari sumur. Ia menghitung waktu yang dibutuhkan katak melompat dengan menghitung banyaknya lompatan yaitu 15 menit dikalikan 10 lompatan dan diperoleh 150 menit. Ia selanjutnya menghitung waktu yang dibutuhkan katak untuk beristirahat yaitu 5 menit dikalikan 9 lompatan diperoleh 45 menit. $\mathrm{T}_{2}$ menentukan lamanya waktu yang diperlukan katak untuk keluar dari sumur yaitu 150 menit ditambahkan 45 menit diperoleh 195 menit atau 3 jam
15 menit. Subjek $T_{1}$ berhasil sampai pada solusi yang benar yaitu menambahkan waktu katak mulai melompat yaitu jam 06.00 dengan 3 jam 15 menit diperoleh 09.15 .

Ia memeriksa kebenaran solusi yang diperoleh dengan mengecek langkah demi langkah penyelesaian masalah dan mengatakan bahwa banyaknya lompatan katak lebih banyak dari banyak istirahat katak yaitu berselisih 1 lompatan. Ia mengatakan bahwa katak harus melompat naik pada lompatan terakhir agar keluar dari sumur. Ia merasa yakin bahwa dengan menggunakan gambar ia akan sampai pada solusi yang benar yaitu menuliskan katak keluar dari sumur pada jam 09.15.

Guru dengan pengalaman mengajar 8 tahun $\left(\mathrm{T}_{1}\right)$ melakukan transisi dari representasi visual $\mathrm{ke}$ representasi verbal secara fleksibel. $\mathrm{T}_{1}$ mengonstruksi representasi untuk mengidentifikasi masalah dan mengenali fakta serta mengilustrasikan konteks yang tersedia pada masalah dengan menggunakan gambar. Hal ini mendukung penelitian sebelumnya (Adu-Gyamfi et al., 2012; Yee \& Bostic, 2014; Zahner \& Corter, 2010) yaitu penggunaan multipel representasi berasosiasi dengan kesuksesan seseorang dalam memecahkan masalah.

Pengalaman mengajar guru juga berkontribusi terhadap kontruksi representasi dan konsepsi guru tentang representasi. Guru $T_{1}$ yang telah mengajar selama 8 tahun meyakini representasi seharusnya menjadi pusat praktik pembelajaran matematika di kelas. $\mathrm{T}_{1}$ sudah menggunakan representasi sebagai alat untuk mengilustrasikan ide-ide matematis. Guru $\mathrm{T}_{1}$ telah menggunakan representasi sebagai bagian integral dari pembelajaran sehari-hari. $\quad \mathrm{T}_{1}$ 
DOI: https://doi.org/10.24127/ajpm.v9i4.3199

memandang representasi sebagai bagian penting dari penjelasan yang diberikan guru tentang konsep baru, ilustrasi proses pemecahan masalah, dan menciptakan koneksi antar konsep matematika. Dalam proses mengenalkan konsep baru, $\mathrm{T}_{1}$ sering menggunakan lebih dari satu representasi untuk mengakomodasi kemampuan setiap siswa.

Hasil wawancara juga mengungkapkan bahwa $\mathrm{T}_{1}$ meyakini representasi dapat digunakan sebagai bahan diskusi dalam pembelajaran matematika. Hal ini bersesuaian dengan penelitian (Selling, 2016; Stylianou,
2010) bahwa pemilihan representasi di kelas, baik itu yang dikonstruksi oleh guru maupun yang dihasilkan siswa, dapat memengaruhi diskusi kelas yang memungkinkan siswa dapat berbagi ide dan pemahaman dan membantu guru memfokuskan perhatian siswa pada koneksi antar konsep matematika.

2. Data Representasi Matematis Guru SMP dengan Pengalaman Mengajar 6 tahun

Hasil pekerjaan guru dengan lama mengajar 6 tahun $\left(T_{2}\right)$ dalam menyelesaikan TRM disajikan pada Gambar 2.

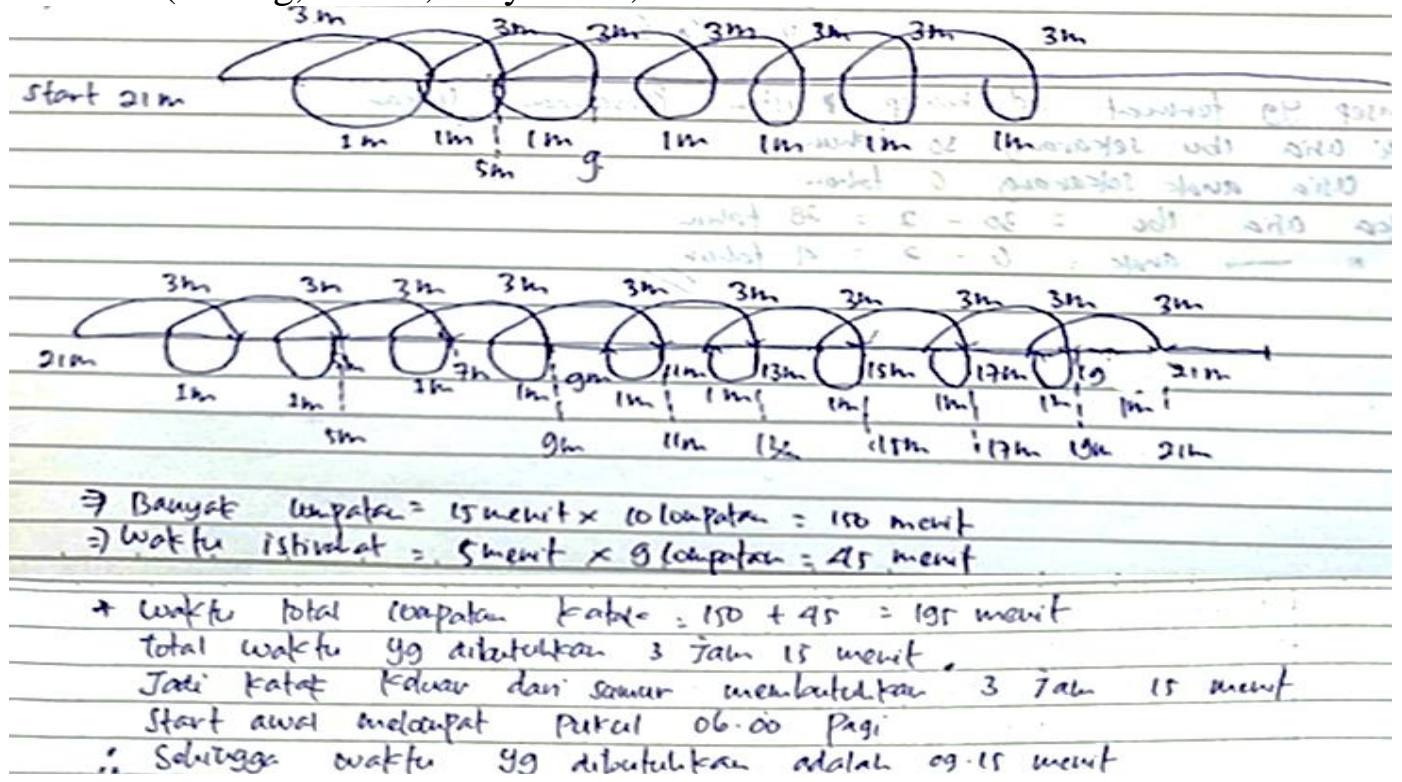

Gambar 2. Pekerjaan Ms. Tere $\left(\mathrm{T}_{2}\right)$

Hasil pekerjaan Ms. Tere pada gambar 2 dan hasil wawancara menunjukkan Ms. Tere $\left(\mathrm{T}_{2}\right)$ menggunakan representasi visual dalam melukiskan informasi yang tersedia di soal. Ia mengorganisasikan dan mengidentifikasi kecukupan informasi agar tiba pada solusi dengan mengonstruksi gambar. Hasil wawancara menunjukkan $\mathrm{T}_{2}$ mengungkapkan bahwa ia perlu menyatakan informasi yang tersedia di soal dalam gambar. $\mathrm{T}_{2}$ mengonstruksi representasi visual untuk mengidentifikasi masalah dan mengenali fakta serta mengilustrasikan konteks yang tersedia pada masalah dengan menggunakan gambar. Ia menggambar lintasan yang dilalui katak sampai keluar dari sumur dalam bentuk sketsa. Ia menggunakan representasi verbal yaitu dengan frase "maju-mundur" agar memudahkan dalam membuat sketsa lintasan katak. Ia membuat garis melengkung seperti bukit dan lembah untuk meng- 
ilustrasikan lintasan katak melompat dan beristirahat.

Dalam menyelesaikan masalah pola bilangan, $\mathrm{T}_{2}$ menggunakan representasi visual sebagai alat monitoring pemecahan masalah yaitu untuk mendeteksi kesalahan dalam pengerjaan soal. Dari hasil pekerjaan terlihat bahwa ia dua kali membuat sketsa agar representasi visual yang dibuat menjadi akurat. Ia menuliskan jarak setiap lompatan katak yaitu 3 meter dan jarak istirahat katak yaitu 1 meter secara detail. Ia menggambar lintasan katak dan mencantumkan panjang lompatan dan istirahat katak berdasarkan kedalaman sumur yaitu 21 meter.

$\mathrm{T}_{2}$ mengenali pola lompatan dan istirahat katak dengan pola $3,5,7$, $9, \ldots, 21$. Ia mengenali pola ini sebagai pola bilangan ganjil. Hal ini mengindikasikan bahwa $\mathrm{T}_{2}$ mampu melihat lompatan dan istirahat katak secara utuh dan mampu mengenali pola lompatan dan istirahat katak. Ia mengatakan bahwa untuk lompatan pertama diperoleh jarak tempuh 3 meter. Pola ini mengalami perubahan yang sama yaitu bertambah 2 meter untuk lintasan selanjutnya.

Ia menghitung waktu lompatan katak dengan menghitung banyaknya lompatan yaitu 10 kemudian dikalikan 15 menit dan diperoleh 195 menit. Ia selanjutnya menghitung waktu istirahat yaitu 9 lompatan dikalikan 5 menit diperoleh 45 menit. Selanjutnya $\mathrm{T}_{2}$ menentukan total waktu yang dibutuhkan katak agar keluar dari sumur yaitu 150 menit ditambah 45 menit diperoleh 195 menit atau 3 jam 15 menit. $\mathrm{T}_{2}$ berhasil sampai pada solusi yang benar yaitu menambahkan waktu awal yaitu jam 06.00 dengan 3 jam 15 menit diperoleh 09.15.
Guru yang memiliki pengalaman mengajar 6 tahun $\left(T_{2}\right)$ meyakini representasi sangat penting dikonstruksi dan digunakan oleh guru dalam membelajarkan konsep matematika. Ia mengatakan bahwa untuk memudahkan siswa dalam memahami suatu konsep matematika, ia menggunakan representasi dengan benda-benda di sekitar siswa. Lebih jauh lagi, $\mathrm{T}_{2}$ memiliki konsepsi bahwa representasi dapat mengurangi tingkat keabstrakan yang ada di soal matematika (Pagiling, 2019). Guru $T_{2}$ menyatakan bahwa representasi itu cara yang berbeda dalam menjelaskan suatu konsep yang sama. Pernyataan ini menunjukkan bahwa konsepsi guru dengan pengalaman mengajar 6 tahun tentang representasi masih terbatas pada produk dan belum proses (Goldin \& Shteingold, 2001; NCTM, 2000; Stylianou, 2010).

$$
\text { Hasil wawancara juga }
$$

mengungkapkan $\mathrm{T}_{2}$ meyakini representasi dapat digunakan sebagai bahan diskusi dalam pembelajaran matematika. Hal ini bersesuaian dengan penelitian (Stylianou, 2011) bahwa pemilihan representasi di kelas, baik itu yang dikonstruksi oleh guru maupun siswa, dapat memengaruhi diskusi kelas dan membantu guru memfokuskan perhatian siswa pada koneksi antar konsep matematika. Guru $\mathrm{T}_{2}$ memulai aktivitas pembelajaran dengan manipulasi fisik untuk mendorong siswa menggunakan strategi mereka sendiri untuk memecahkan masalah dan memahami matematika. $\mathrm{T}_{2}$ juga menyebutkan representasi yang beragam pada pembelajaran di kelas dapat mengakomodasi gaya belajar dan kemampuan siswa. Hal ini mendukung penelitian sebelumnya bahwa representasi multipel guru dapat menjamin kesetaraan pengetahuan dan pemahaman siswa terhadap suatu ide 
matematis (Selling, 2016; Stylianou, 2010). Namun, guru T2 belum mempertimbangkan representasi sebagai ide sentral pada pembelajaran matematika di SMP. Guru T2 meyakini representasi hanya sesuai diterapkan untuk kelas yang didominasi oleh siswa berkemampuan tinggi.

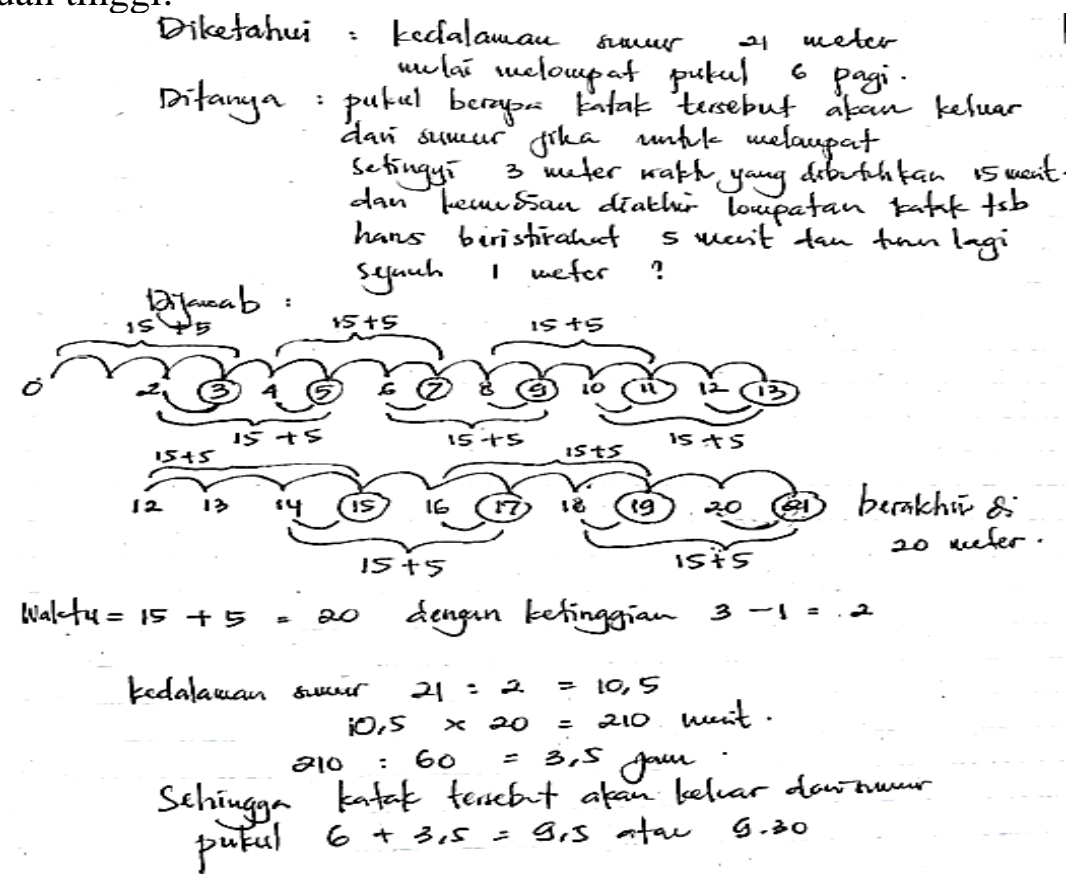

Gambar 3. Pekerjaan Ms Tasya $\left(\mathrm{T}_{3}\right)$

Gambar 3 menunjukkan bahwa T3 mengilustrasikan informasi yang tersedia di masalah dalam bentuk sketsa. Selanjutnya, T3 membuat dan melaksanakan rencana penyelesaian secara simbolik yaitu menuliskan waktu permulaan katak melompat yaitu pukul 06.00. Ia kemudian menghitung waktu yang dibutuhkan katak untuk melompat selama 15 menit dan waktu istirahat katak selama 5 menit sehingga diperoleh 20 menit untuk menempuh jarak 2 meter.

Ia mengenali pola bahwa setiap pertambahan 20 menit katak mengalami pertambahan jarak sejauh 2 meter. Ia mengulangi pola tersebut sampai sebelas kali. Namun, di pola ke-10 dan ke-11 ia mengalami kesalahan
3. Data Representasi Matematis Guru SMP dengan Pengalaman Mengajar 3 Tahun

Hasil pekerjaan guru dengan lama mengajar 3 tahun (T3) dalam menyelesaikan masalah pola bilangan pada TRM disajikan pada Gambar 3. 
sumur yang memiliki kedalaman 21 meter dengan sketsa yang dibuat pada pola ke-10 dan ke-11. Dari pekerjaan di pola ke-11 ia melakukan representasi simbolik yang salah yaitu ia menambahkan waktu melompat dan waktu istirahat katak kemudian dibagi dua agar bersesuaian dengan jarak yang masih dibutuhkan yaitu 1 meter untuk keluar dari sumur yang memiliki kedalaman sumur 21 meter.

Hasil pekerjaan pada masalah pola bilangan yang dikonfirmasi wawancara menunjukkan bahwa Ms. Tasya $\left(\mathrm{T}_{3}\right)$ menggunakan representasi visual yaitu membuat sketsa dalam melukiskan informasi yang tersedia di soal. $\mathrm{T}_{3}$ mengungkapkan rencana atau strategi penyelesaian bahwa ia perlu menyatakan informasi yang tersedia di soal dalam bentuk formula matematika. Selain itu, $\mathrm{T}_{3}$ merasa yakin sampai solusi dengan menggunakan representasi simbolik.

Namun, saat menyelesaikan masalah ia memiliki ketergantungan pada representasi simbolik dan mengalami kegagalan dalam melakukan translasi dari representasi simbolik ke visual. Ia tetap menggunakan pola setiap 20 menit katak mengalami pertambahan jarak 2 meter tanpa melakukan interpretasi yang akurat terhadap representasi yang dikonstruksi. Dalam penyelesaian masalah ia menggunakan representasi simbolik yaitu ekspresi matematis dalam bentuk pola bilangan. Namun, ia tidak dapat sampai ke solusi yang benar karena representasi simbolik yang dikonstruksi kurang lengkap dan akurat. Ia tidak dapat menggambarkan lintasan katak sebagai suatu kesatuan yang utuh. Representasi visual yang dikontruksi guru $\mathrm{T}_{3}$ juga tidak akurat dan ia lebih mengandalkan representasi simbolik dan verbal. Namun, ia tidak dapat mengilustrasikan informasi atau faktafakta yang tersedia di soal ke bentuk atau ekspresi matematis yang tepat.

Hasil wawancara menunjukkan bahwa $\mathrm{T}_{3}$ memiliki konsepsi bahwa representasi sebagai alat menuju pemahaman konsep matematika. Guru $\mathrm{T}_{3}$ yang memiliki pengalaman mengajar 3 tahun meyakini representasi itu penting dalam menjelaskan konsep matematika untuk memudahkan siswa memahami suatu konsep namun ia jarang melatihkan soal atau tugas menantang yang menuntut penggunaan multipel representasi siswa dalam pembelajaran matematika di kelas. Pengalaman mengajar $\mathrm{T}_{3}$ yang masih minim berasosiasi dengan penggunaan representasi dalam pembelajaran matematika. Ia belum menggunakan representasi sebagai bahan diskusi untuk berbagi pengetahuan dan pemahaman ide-ide matematis. Lebih jauh lagi, ia memiliki konsepsi tentang representasi hanya sebagai produk yaitu gambaran atau bayangan untuk mengilustrasikan ide-ide matematis (Selling, 2016; Stylianou, 2010). Dalam menjelaskan konsep matematika $\mathrm{T}_{3}$ cenderung menggunakan contoh bendabenda dalam kehidupan sehari-hari siswa agar memudahkan pemahaman siswa.

Penelitian ini memberikan implikasi teoritis yaitu konsepsi guru tentang representasi belum menyeluruh. Selain itu, pengalaman mengajar beasosiasi dengan konsepsi guru tentang representasi dalam pembelajaran matematika. Dua guru masing-masing yang memiliki pengalaman mengajar 3 dan 6 tahun memahami representasi semata-mata sebagai alat untuk memahami konsep matematika dan memecahkan masalah. Kedua guru belum meyakini representasi sebagai pusat praktik pembelajaran matematika. 
DOI: https://doi.org/10.24127/ajpm.v9i4.3199

Hasil penelitian ini mendukung penelitian sebelumnya (Rau \& Matthews, 2017; Stylianou, 2010) bahwa pembelajaran dengan representasi akan menciptakan pembelajaran yang bermakna dan kaya dengan konteks.

Temuan penelitian ini menganjurkan guru matematika untuk memulai pembelajaran dengan representasi sebagai aktivitas matematika untuk memfasilitasi ber-pikir siswa dalam mengonstruksi pemahaman ideide matematis. Selain itu, pembelajaran bisa dimulai dengan menggunakan benda-benda di sekitar agar siswa bisa bereksplorasi dengan realitas dikehidupan sehari-hari dalam mengkonstruksi pemahaman dan pengetahuan matematika secara mandiri. Temuan lain, guru sebaiknya tidak memberikan formula-formula matematika secara langsung tetapi memberikan kesempatan yang luas kepada siswa dalam berdiskusi untuk berbagi pemahaman dan pengetahuan matematika di dalam ruang kelas sehingga guru perlu mengubah paradigma mengajar dari tradisional menjadi lebih konstruktivis dengan mengedepankan pedagogi representasi.

Penelitian ini berfokus hanya pada tiga guru SMP sehingga hasil penelitian ini tidak dapat digeneralisasikan kepada semua guru. Namun, penelitian skala kecil lebih sesuai menggunakan pendekatan kualitatif yang bertujuan untuk mengeksplorasi konsepsi guru SMP tentang peran representasi pada pembelajaran matematika. Penelitian skala besar masih diperlukan untuk menguji keefektifan aspek konsepsi guru tentang representasi matematis yang diidentifikasi untuk mempromosikan pembelajaran guru dalam skala yang lebih besar.

\section{KESIMPULAN DAN SARAN}

Representasi yang dikonstruksi oleh ketiga guru matematika SMP dalam menyelesaikan soal cerita berbeda antara satu dengan lainnya. Guru dengan pengalaman mengajar 6 tahun dan 8 tahun berhasil memecahkan masalah pola bilangan. Pengalaman mengajar menjadi aspek bagi guru dalam mengonstruksi dan mengilustrasikan konsep matematika, membuat, menafsirkan, dan menghubungkan representasi sebagai praktik penting untuk melakukan, mempelajari dan membelajarkan matematika. Ketiga guru meyakini bahwa representasi sangat penting dalam proses pembelajaran matematika di kelas. Namun, hanya guru matematika dengan pengalaman mengajar 8 tahun yang memiliki konsepsi bahwa representasi sebagai pusat praktik pembelajaran matematika di kelas. Guru dengan pengalaman mengajar 3 tahun dan 6 tahun masih menggunakan dan mengonstruksi representasi sebagai produk yaitu sebagai alat dalam menyelesaikan soal.

Penelitian ini menyediakan lensa bahwa guru dengan pengalaman mengajar yang lama telah menggunakan representasi dalam berpikir dan berkomunikasi matematis. Penelitian selanjutnya dapat mengkaji tugas-tugas matematika menantang yang menuntut penggunaan representasi dan kaitannya dengan keyakinan dan kemampuan pedagogis guru.

\section{UCAPAN TERIMA KASIH}

Penulis mengucapkan terima kasih kepada Kementerian Riset dan Teknologi/Badan Riset Inovasi Nasional atas dana yang diberikan untuk melaksanakan penelitian melalui skema penelitian dosen pemula tahun 2019. Penulis juga mengucapkan 
DOI: https://doi.org/10.24127/ajpm.v9i4.3199

kepada ketiga guru yang bersedia menjadi subjek penelitian pada masa pandemi ini.

\section{DAFTAR PUSTAKA}

Adu-Gyamfi, K., Bossé, M. J., \& Stiff, L. V. (2012). Lost in Translation: Examining Translation Errors Associated With Mathematical Representations. School Science and Mathematics, 112(3), 159170.

Anantharajan. (2020). Teacher Noticing of Mathematical Thinking in Young Children's Representations of Counting. Journal for Research in Mathematics Education, 51(3), 268.

https://doi.org/10.5951/jresemthed uc-2019-0068

Boonen, A. J. H., Van Wesel, F., Jolles, J., \& Van der Schoot, M. (2014). The role of visual representation type, spatial ability, and reading comprehension in word problem solving: An item-level analysis in elementary school children. International Journal of Educational Research, 68, 15-26. https://doi.org/10.1016/j.ijer.2014. 08.001

Dreher, A., \& Kuntze, S. (2015). Teachers' professional knowledge and noticing: The case of multiple representations in the mathematics classroom. Educational Studies in Mathematics, 88(1), 89-114. https://doi.org/10.1007/s10649014-9577-8

Goldin, G. A. (2000). Affective Pathways and Representation in Mathematical Problem Solving. Mathematical Thinking and Learning, 2(3), 209-219. https://doi.org/10.1207/s15327833 mt10203_3

Goldin, G. A., \& Shteingold, N. (2001). System of mathematical representations and development of mathematical concepts. In A. A. Cuoco (Ed.), The Roles of Representation in School Mathematics (pp. 1-23). National Council of Teachers of Mathematics.

Hoogland, K., de Koning, J., Bakker, A., Pepin, B. E. U., \& Gravemeijer, K. (2018). Changing representation in contextual mathematical problems from descriptive to depictive: The effect on students' performance. Studies in Educational Evaluation, 58(November 2017), 122-131. https://doi.org/10.1016/j.stueduc.2 018.06.004

Huang, R., \& Cai, J. (2011). Pedagogical representations to teach linear relations in Chinese and U.S. classrooms: Parallel or hierarchical? Journal of Mathematical Behavior, 30(2), 149-165.

https://doi.org/10.1016/j.jmathb.20 11.01.003

Kang, R., \& Liu, D. (2018). The Importance of Multiple Representations of Mathematical Problems: Evidence from Chinese Preservice Elementary Teachers' Analysis of a Learning Goal. International Journal of Science and Mathematics Education, 16(1), 125-143.

https://doi.org/10.1007/s10763016-9760-8

Lee, M. Y., \& Lee, J. E. (2019). Preservice teachers' perceptions of the use of representations and suggestions for students' incorrect use. Eurasia Journal of Mathematics, Science and Technology Education, 15(9). https://doi.org/10.29333/ejmste/10 3055 
Mitchell, R., Charalambous, C. Y., \& Hill, H. C. (2014). Examining the task and knowledge demands needed to teach with representations. Journal of Mathematics Teacher Education, 17(1), 37-60. https://doi.org/10.1007/s10857013-9253-4

NCTM. (2000). Principles and standards for school mathematics (Vol. 1). National Council of Teachers of Mathematics.

Pagiling, S. L. (2019). Exploration of students' representation in solving pythagorean theorem problems based on cognitive style. Journal of Physics: Conference Series, 1321(3), 1-6. https://doi.org/10.1088/17426596/1321/3/032004

Panasuk, R. M., \& Beyranevand, M. L. (2010). Algebra Students' Ability to Recognize Multiple Representations and Achievement. International Journal for Mathematics Teaching and Learning. http://www.eric.ed.gov/ERICWeb Portal/detail?accno=EJ904885

Rau, M. A., \& Matthews, P. G. (2017). How to make 'more' better? Principles for effective use of multiple representations to enhance students' learning about fractions. ZDM - Mathematics Education, 49(4), 531-544. https://doi.org/10.1007/s11858017-0846-8

Santia, I., Purwanto, Sutawidjadja, A., Sudirman, \& Subanji. (2019). Exploring mathematical representations in solving ill- structured problems: The case of quadratic function. Journal on Mathematics Education, 10(3), 365-378. https://doi.org/10.22342/jme.10.3.7 600.365-378

Selling, S. K. (2016). Learning to represent, representing to learn. Journal of Mathematical Behavior, 41, 191-209. https://doi.org/ 10.1016/j.jmathb.2015.10.003

Stylianou, D. A. (2010). Teachers' conceptions of representation in middle school mathematics. Journal of Mathematics Teacher Education, 13(4), 325-343. https://doi.org/10.1007/s10857010-9143-y

Stylianou, D. A. (2011). An examination of middle school students' representation practices in mathematical problem solving through the lens of expert work: Towards an organizing scheme. Educational Studies in Mathematics, 76(3), 265-280. https://doi.org/10.1007/s10649010-9273-2

Yee, S. P., \& Bostic, J. D. (2014). Developing a contextualization of students' mathematical problem solving. Journal of Mathematical Behavior, 36, 1-19. https://doi.org/10.1016/j.jmathb.20 14.08.002

Zahner, D., \& Corter, J. E. (2010). The process of probability problem solving: Use of external visual representations. Mathematical Thinking and Learning, 12(2), 177-204. https://doi.org/10.1080/109860610 03654240 